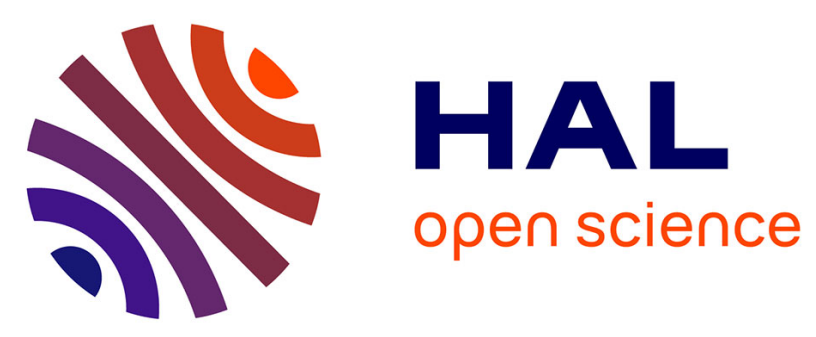

\title{
Preparation and characterization of functionalized hybrid hydroxyapatite from phosphorite and its potential application to $\mathrm{Pb} 2+$ remediation
}

Hassen Bachoua, Guillaume Renaudin, Béchir Badraoui, Fabrice Leroux, Mongi Debbabi, Jean-Marie Nedelec

\section{To cite this version:}

Hassen Bachoua, Guillaume Renaudin, Béchir Badraoui, Fabrice Leroux, Mongi Debbabi, et al.. Preparation and characterization of functionalized hybrid hydroxyapatite from phosphorite and its potential application to Pb2+ remediation. Journal of Sol-Gel Science and Technology, 2016, 78 (3), pp.621-631. 10.1007/s10971-016-3978-3 . hal-01311359

\author{
HAL Id: hal-01311359 \\ https://hal.science/hal-01311359
}

Submitted on 4 May 2016

HAL is a multi-disciplinary open access archive for the deposit and dissemination of scientific research documents, whether they are published or not. The documents may come from teaching and research institutions in France or abroad, or from public or private research centers.
L'archive ouverte pluridisciplinaire HAL, est destinée au dépôt et à la diffusion de documents scientifiques de niveau recherche, publiés ou non, émanant des établissements d'enseignement et de recherche français ou étrangers, des laboratoires publics ou privés. 


\title{
Preparation and characterization of functionalized
}

\section{hybrid hydroxyapatite from phosphorite and its}

\section{potential application to $\mathrm{Pb}^{2+}$ remediation}

\author{
Hassen Bachoua ${ }^{a, c}$, Guillaume Renaudin ${ }^{c, d^{*}}$, Béchir Badraoui ${ }^{a, b}$, Fabrice Leroux ${ }^{d}$, \\ Mongi Debbabi ${ }^{a}$, Jean-Marie Nedelec ${ }^{c, d}$
}

${ }^{\text {a }}$ Laboratoire de Physico-Chimie des Matériaux, Université de Monastir, Faculté des Sciences, 5019 Monastir, Tunisie

${ }^{\mathrm{b}}$ Institut Préparatoire aux Etudes d'Ingénieur de Monastir, Université de Monastir, 5019 Monastir, Tunisie

${ }^{c}$ Clermont Université, ENSCCF, Institut de Chimie de Clermont-Ferrand, BP 10448, 63000 Clermont-Ferrand, France

${ }^{\mathrm{d}}$ CNRS, UMR 6296, 63177 Aubière, France

\footnotetext{
* Corresponding author: Prof Guillaume Renaudin, ENSCCF, Institut de Chimie de ClermontFerrand, Clermont-Ferrand, France.

E-mail address: guillaume.renaudin@ensccf.fr
} 


\section{HIGHLIGHTS}

In this paper :

- hybrids hydroxyapatites incorporating organic aspartate and glutamate anions have been prepared

- thanks to the use of a complete set of techniques, the efficiency of the incorporation has been evidenced with a mechanism dependant on the nature of the organic anion

- $\quad$ sorption isotherms have been analyzed and have shown that the $\mathrm{Pb}^{2+}$ sorption capacity is increased for hybrid materials with a single active site 


\begin{abstract}
Calcium hydroxyapatite-aspartate (CaHAp-Asp) and calcium hydroxyapatite-glutamate (CaHAp-Glu) hybrid materials were prepared by the dissolution of Tunisian Phosphate Rocks in concentrated nitric acid and re-precipitation in basic solution in the presence of aspartic and glutamic acids. Chemical analyses, X-Ray Powder Diffraction, Infrared spectroscopy, ${ }^{13} \mathrm{C}$ MAS-NMR spectroscopy, ThermoGravimetry and Scanning Electron Microscopy were used to characterize the materials and also the organic-inorganic interfaces. All techniques converge to the formation of hybrid organic-inorganic compounds composed of hydroxyapatite solids with organic anions incorporated at the surface. XRPD and SEM observations showed that not only was the crystallinity significantly affected by the presence of organic anions, but also the structural and morphological properties. The presence of organic anions has been confirmed by IR and ${ }^{13} \mathrm{C}$ MS-NMR spectroscopies, and their amount has been evaluated by TG and chemical analyses. The three CaHAp, CaHAp-Asp and CaHAp-Glu materials were evaluated for $\mathrm{Pb}^{2+}$ sorption from aqueous solutions. Sorption isotherms have been analyzed using Langmuir and Freundlich models showing that the $\mathrm{Pb}^{2+}$ sorption capacity is increased for CaHAp-Asp and CaHAp-Glu. The comparison of the two models indicates a single active site corresponding to a homogeneous interface between $\mathrm{Pb}^{2+}$ aqueous adsorbate and the solid adsorbent surface.
\end{abstract}

KEYWORDS: Hydroxyapatite, hybrid materials, carboxylic acids, lead sorption. 


\section{INTRODUCTION}

Phosphorite, or phosphate rock, is a general term which refers to a non-detrital sedimentary rock which contains high amounts of phosphate-bearing minerals. The phosphate is present as hydroxyapatite $\left(\mathrm{Ca}_{10}\left(\mathrm{PO}_{4}\right)_{6}(\mathrm{OH})_{2}\right)$, fluorapatite $\left(\mathrm{Ca}_{10}\left(\mathrm{PO}_{4}\right)_{6} \mathrm{~F}_{2}\right)$ and carbonated fluorapatite (phosphate to carbonate substitution). Apatite minerals in igneous and metamorphic rocks generally approach fluorapatite composition ${ }^{l}$. The principal phosphate mineral in sedimentary phosphorites is carbonated fluorapatite ${ }^{2}$. Tunisian Phosphate Rock (TPR) is already used in the manufacture of phosphoric acid and phosphate fertilizers ${ }^{3}$. The aim of this study is to prepare apatitic material from TPR for an environmental application; i.e. for pollutant remediation of industrial wastes containing $\mathrm{Pb}^{2+}$ cations. The synthesis methods of stoichiometric calcium apatite are numerous and widely studied. In our work, we applied the preparation method described in the literature ${ }^{4,5}$ starting from natural TPR as precursors to obtain single-phase hydroxyapatite samples. The optimized synthesis route allowed hydroxyapatite (CaHAp) to be prepared from natural rock more quickly and in a manner that is cheaper than with other methods, and the introduction of organic acids in the first step of the synthesis led to functionalized hybrid hydroxyapatite. The applications of grafted hydroxyapatite are based on their physicochemical properties and surface reactivity ${ }^{6}$. The hydroxyapatite has a very reactive surface owing to the presence of two functional active sites $^{7}$. Furthermore, several studies have been carried out on the functionalization of the apatite surface, such as the grafting of organic moieties (carboxylic acid, amino acid, phosphonates...) onto the apatite surface ${ }^{8-10}$. In another study, it was found that the organic moieties can replace the hydroxyl group of the apatitic structure ${ }^{11-16}$. The apatite structure is also characterized by the presence of channels that can also contribute to adsorption mechanisms. The adsorption of heavy metals such as lead, cobalt, cadmium and copper has 
been widely studied by considering different materials, including apatite in recent years. Lead is one of the most widespread heavy metals present in the environment. $\mathrm{Pb}^{2+}$ is present in the environment in the form of highly soluble minerals such as $\mathrm{PbO}, \mathrm{Pb}\left(\mathrm{CO}_{3}\right)_{2}$, and $\mathrm{PbSO}_{4}{ }^{17}$. For remediation of $\mathrm{Pb}$ contamination, phosphate minerals (especially apatites) were suggested ${ }^{18-20}$. The apatites studied came from different origins; including synthetic hydroxyapatites, apatites of biological origin such as bone meal and also natural phosphate rock $^{21-28}$.

The aim of the present study is the synthesis and physicochemical characterization of two grafted hydroxyapatite samples: the calcium hydroxyapatite-aspartate (CaHAp-Asp) and the calcium hydroxyapatite-glutamate (CaHAp-Glu) hybrid material prepared from TPR. The chemical composition, structure and surface property of samples were investigated. The removal of toxic $\mathrm{Pb}^{2+}$ cations from solution was investigated on the two grafted hydroxyapatite samples (CaHAp-Asp and CaHAp-Glu) and compared with an inorganic hydroxyapatite sample (CaHAp). Adsorption isotherms were determined and modeled with Freundlich and Langmuir equations. We identified the existence of a single active site that fixed $\mathrm{Pb}^{2+}$ aqueous cations at the hydroxyapatite surface, with a bonding energy that was considerably increased in the presence of grafted organic anions at the interface.

\section{EXPERIMENTAL SECTION}

\subsection{Preparation of pristine and grafted hydroxyapatites}

The hydroxyapatite (CaHAp) obtained from the Tunisian Phosphate Rock (TPR) was synthesized by a first dissolution of TPR in nitric acid ${ }^{29}$. The acid dissolution of the TPR is realized by the addition of $20 \mathrm{~mL}$ of nitric acid $\left(\mathrm{HNO}_{3}\right)(65 \%)$ to $500 \mathrm{~mL}$ of distilled water and $30 \mathrm{~g}$ of TPR. The reaction mixture was stirred for 3 hours at room temperature. Insoluble 
minerals were then separated out by filtration. The filtrate obtained was then neutralized by the addition of concentrated $\mathrm{NH}_{4} \mathrm{OH}$ solution (25\%). The mixture was stirred for 3 hours at $90^{\circ} \mathrm{C}$. The precipitate was then filtrated, washed with hot distilled water and dried at $110^{\circ} \mathrm{C}$ for 24 hours.

Functionalized hydroxyapatite samples were synthesized using aspartic acid $\left(\mathrm{C}_{4} \mathrm{H}_{7} \mathrm{NO}_{4}\right)$ and glutamic acid $\left(\mathrm{C}_{5} \mathrm{H}_{9} \mathrm{NO}_{4}\right)$. Organic acids were added simultaneously with nitric acid during TPR dissolution considering the three following amounts: 1, 5 and $10 \mathrm{mmol}$. The prepared samples are labeled as follows: $\left(\mathrm{CaHAp}-\mathrm{Asp} \mathrm{x}_{\mathrm{x}}\right)$ and $\left(\mathrm{CaHAp}-\mathrm{Glu}_{\mathrm{x}}\right)$ with $\mathrm{x}=1,5$ and 10 .

\subsection{Characterization techniques}

Ca concentration was determined by Atomic Absorption Spectroscopy using a Perkin-Elmer 3110 spectrophotometer. The phosphorus content was determined by the formation of phosphovanado molybdic complex with yellow coloring by measurement of the optical densities at $430 \mathrm{~nm}^{30}$. The chemical analysis of carbon was determined by TOC-L Laboratory Total Organic Carbon Analyzers. X-Ray Powder Diffraction analyses were carried out on an X'Pert Pro PANalytical diffractometer using $\mathrm{Cu} \mathrm{K \alpha}$ radiation $(\lambda=1.5418 \AA)$, with $\theta-\theta$ geometry, equipped with an $\mathrm{X}^{\prime}$ Celerator solid detector and a Ni filter. The $2 \theta$ range was from $15^{\circ}$ to $120^{\circ}$ at a scanning speed of $0.0167^{\circ} /$ minute. Refinements of the lattice and microstructural parameters of hydroxyapatite were performed with the Rietveld method ${ }^{31}$ using the Fullprof program ${ }^{32}$. Thermogravimetric analyses were carried out in airflow using a TGA-DSC 1 Star system from Mettler-Toledo. Heating was performed in the range of $25^{\circ} \mathrm{C}$ to $1000^{\circ} \mathrm{C}$ with a heating rate of $5^{\circ} \mathrm{C} / \mathrm{min}$. Fourier Transform Infrared spectra were recorded using a Nicolet FT 5700 spectrophotometer equipped with a diamond ATR setup in the range of $4000-400 \mathrm{~cm}^{-1}$. Solid state ${ }^{13} \mathrm{C}$ NMR spectra were recorded on a $300 \mathrm{MHz}$ Bruker 
spectrometer at $75.4 \mathrm{MHz}$, using a magic angle spinning (MAS) condition at $10 \mathrm{kHz}$ and a 4 $\mathrm{mm}$ diameter size zirconia rotor. ${ }^{13} \mathrm{C}$ spectra obtained via the proton-enhanced crosspolarization method $(\mathrm{CP})$ were referenced to the carbonyl of the glycine calibrated at 176.03 ppm. Recycling and Hartman-Hahn contact times were $5 \mathrm{~s}$ and $1250 \mu$ s, respectively. Spinal64 ${ }^{1} \mathrm{H}$ phase-decoupling was applied during ${ }^{13} \mathrm{C}$ channel acquisition. In order to obtain a proper signal-to-noise ratio for the hybrid $\mathrm{Zn}$ phase, up to 5,000 scans were needed. The morphology of samples was characterized using a scanning electron microscope (SEM) Zeiss Supra 55 type VP in low voltage.

Specific surface area has been measured by gas sorption with a Quantachrome MP-Autosorb1 equipment at $77 \mathrm{~K}$. At least seven points in the $0,05-0,3 \mathrm{p} / \mathrm{p}_{0}$ range were measured and used for calculations.

\subsection{Sorption experiments}

Synthetic aqueous solutions of different concentrations of lead were prepared from lead nitrate $\left[\mathrm{Pb}\left(\mathrm{NO}_{3}\right)_{2}\right]$. The adsorptions of lead ions on CaHAp, CaHAp-Asp 10 and CaHAp-Glu 10 were performed by contacting $0.2 \mathrm{~g}$ of the synthesized powder in $100 \mathrm{~mL}$ of the lead solution at $25{ }^{\circ} \mathrm{C}$ (initial $\mathrm{pH}=5$ ). At the end of the adsorption test, powder was filtered from the solution and the supernatant was analyzed for residual $\mathrm{Pb}^{2+}$ concentration by Palintest Scanning Analyze SA1100 with Precision Range 2-100 $\mu \mathrm{g} / \mathrm{l}$. Two replicates were used for each $\mathrm{Pb}^{2+}$ sorption experiment and the results given were the average values. The adsorption capacity of the inorganic and hybrid hydroxyapatite samples were calculated using the general equation $(1):{ }^{33}$

$$
q_{a}=\frac{\left(C_{0}-C_{t}\right) V}{m}
$$


Where $q_{a}$ is the amount of $\mathrm{Pb}^{2+}$ adsorbed on the sample surface, $C_{0}$ and $C_{t}$ are the concentrations of metal cation $(\mathrm{mmol} / \mathrm{L})$ in the liquid phase initially and at time $\mathrm{t}, V$ is the volume of the medium (L) and $m$ is the amount of apatite $(\mathrm{g})$.

\section{RESULTS AND DISCUSSION}

\subsection{Physicochemical characterization of the samples}

\subsubsection{Quantification of grafting}

The chemical compositions of CaHAp, CaHAp-Asp $\mathrm{x}_{\mathrm{x}}$ and CaHAp-Glu $\mathrm{C}_{\mathrm{x}}$ determined from elemental analyses are summarized in Table 1 . The CaHAp sample shows a $\mathrm{Ca} / \mathrm{P}$ molar ratio very close to the targeted stoichiometric value of 1.67 . This $\mathrm{Ca} / \mathrm{P}$ ratio increases continuously with the amount of organic anion grafted for the hybrid samples both for glutamate and aspartate (up to 1.73 for CaHAp-Glu ${ }_{10}$ and 1.79 for CaHAp-Asp ${ }_{10}$ ), indicating a possible depletion in phosphate anions. The presence of the organic anion in the precipitated material is attested and quantified by the total carbon analysis, showing a regular increase of the carbon amount together with the increase of the organic acid concentration. This is consistent with the formation of an inorganic-organic hybrid apatitic material. The presence of carbon in the pristine CaHAp sample can be attributed to atmospheric carbonation. Thus, an absolute quantification of the organic anions in the hybrid samples is difficult, but can be estimated as follows: approx. $0.13,0.35$ and 0.56 moles of aspartate anions per mole of $\mathrm{Ca}_{10}\left(\mathrm{PO}_{4}\right)_{6}(\mathrm{OH})_{2}$ for CaHAp-Asp ${ }_{1}, \mathrm{CaHAp}_{\mathrm{Asp}}$ and CaHAp-Asp $\mathrm{A}_{10}$ samples respectively, and approx. 0.12, 
0.28 and 0.34 moles of glutamate anions per mole of $\mathrm{Ca}_{10}\left(\mathrm{PO}_{4}\right)_{6}(\mathrm{OH})_{2}$ for CaHAp-Glu CaHAp-Glu and CaHAp-Glu $_{10}$ samples respectively.

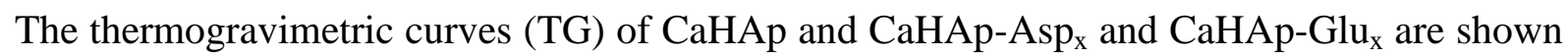
in Figure 1. All samples present a first thermal event between room temperature and $250^{\circ} \mathrm{C}$ due to water desorption. For the pure CaHAp sample, a second weight loss is observed between $800^{\circ} \mathrm{C}$ and $900^{\circ} \mathrm{C}$ due to decarbonation (carbonate contamination) ${ }^{34}$. This weight loss is correlated with the observed carbon content in this sample. For hybrid samples, a supplementary event between $250^{\circ} \mathrm{C}$ and $500^{\circ} \mathrm{C}$ is characteristic of the organic anion decomposition. Table 2 gathers the relative weight losses in the three temperatures ranges $25^{\circ} \mathrm{C}-250^{\circ} \mathrm{C}, 250^{\circ} \mathrm{C}-500^{\circ} \mathrm{C}$ and $500^{\circ} \mathrm{C}-1000^{\circ} \mathrm{C}$ attributed to dehydration, organic anion decomposition and decarbonation respectively.

Table 1. Chemical analysis (weight percent) of the different synthesized hydroxyapatites.

\begin{tabular}{|l|l|l|l|l|}
\hline \multirow{2}{*}{ Sample } & \multicolumn{3}{|l|}{ Weight percent $(\mathrm{Wt} \%)$} & $\mathrm{Ca} / \mathrm{P}$ \\
& $\mathrm{Ca}$ & $\mathrm{P}$ & $\mathrm{C}$ & \\
\hline CaHAp & 37.48 & 17.18 & 0.09 & 1.69 \\
\hline CaHAp-Asp 1 & 37.05 & 16.84 & 0.73 & 1.70 \\
CaHAp-Asp $_{5}$ & 36.82 & 16.26 & 1.78 & 1.75 \\
CaHAp-Asp $_{10}$ & 35.63 & 15.42 & 2.78 & 1.79 \\
\hline CaHAp-Glu $_{1}$ & 37.16 & 16.91 & 0.82 & 1.70 \\
CaHAp-Glu $_{5}$ & 36.85 & 16.53 & 1.75 & 1.72 \\
CaHAp-Glu $_{10}$ & 36.52 & 16.21 & 2.11 & 1.73 \\
\hline
\end{tabular}

Table 2. Weight losses observed in thermogravimetric analysis

\begin{tabular}{|l|l|l|l|l|}
\hline Samples & $\begin{array}{l}\text { Water weight loss } \\
25^{\circ} \mathrm{C}-250^{\circ} \mathrm{C} \\
(\% \mathrm{wt})\end{array}$ & $\begin{array}{l}\text { Organic molecule } \\
\text { weight loss } \\
250^{\circ} \mathrm{C}-500^{\circ} \mathrm{C} \\
(\% \mathrm{wt})\end{array}$ & $\begin{array}{l}\text { Carbonate weight loss } \\
500^{\circ} \mathrm{C}-1000^{\circ} \mathrm{C} \\
(\% \mathrm{wt})\end{array}$ & $\begin{array}{l}\text { Total weight } \\
\text { loss (\%wt) }\end{array}$ \\
\hline CaHAp & 2.41 & 1.03 & 1.25 & 4.69 \\
\hline CaHAp-Asp 1 & 5.58 & 2.37 & 1.25 & 4.69 \\
\hline
\end{tabular}




\begin{tabular}{|l|l|l|l|l|}
\hline CaHAp-Asp & 5.69 & 6.05 & 1.44 & 9.39 \\
CaHAp-Asp & 6.16 & 8.35 & 2.69 & 14.43 \\
\hline CaHAp-Glu $_{1}$ & 5.18 & 2.68 & 1.49 & 9.35 \\
CaHAp-Glu $_{5}$ & 4.76 & 5.62 & 2.29 & 12.67 \\
CaHAp-Glu $_{10}$ & 7.18 & 5.66 & 2.09 & 14.93 \\
\hline
\end{tabular}



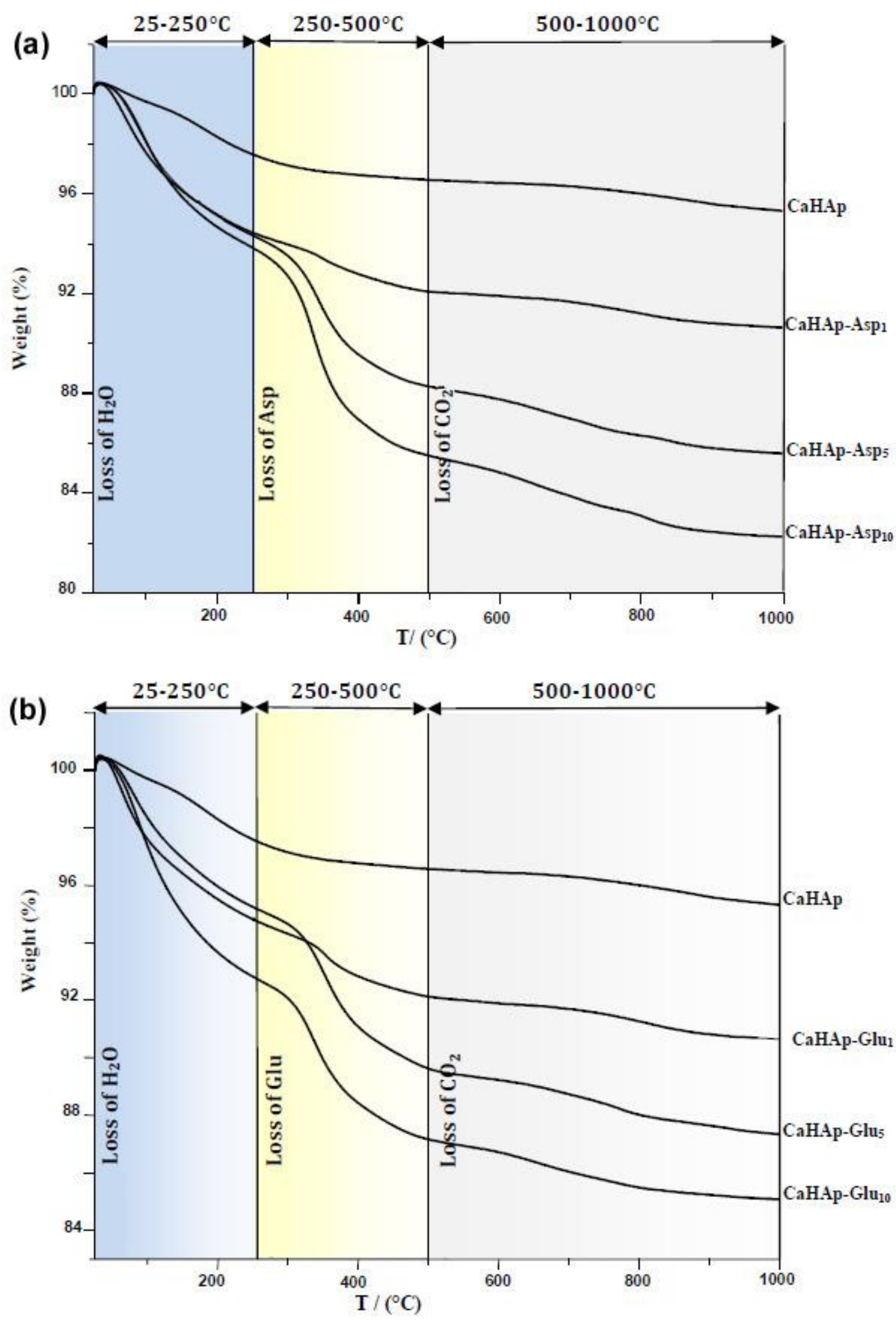

Figure 1. Thermogravimetric curves for CaHAp sample compared to the curves of the various CaHAp-Asp (a) and CaHAp-Glu (b) samples. 
The amount of grafted organic anions can be estimated with the relative weight loss of the second event (subtracting the weight loss observed in this region for the purely inorganic CaHAp sample; i.e. 1.03\%). The TG curves also clearly indicate that hybrid materials were over-hydrated compared to the inorganic hydroxyapatite sample. As for organic anions, the amount of additional water molecules (certainly physisorbed at the CaHAp surface, together with the organic anions) can be roughly estimated from weight loss observed between $25^{\circ} \mathrm{C}$ and $250^{\circ} \mathrm{C}$. Hybrid composition formulations can be deduced as presented below. These obtained values are in good agreement with the previously indicated composition obtained from chemical analyses:

$$
\begin{aligned}
& \mathrm{Ca}_{10}\left(\mathrm{PO}_{4}\right)_{6}(\mathrm{OH})_{2} \cdot 0.1 \mathrm{Asp} \cdot 1.7 \mathrm{H}_{2} \mathrm{O} \text { for CaHAp-Asp } \\
& \mathrm{Ca}_{10}\left(\mathrm{PO}_{4}\right)_{6}(\mathrm{OH})_{2} \cdot 0.4 \mathrm{Asp} \cdot 2.0 \mathrm{H}_{2} \mathrm{O} \text { for CaHAp-Asp } \\
& \mathrm{Ca}_{10}\left(\mathrm{PO}_{4}\right)_{6}(\mathrm{OH})_{2} \cdot 0.6 \mathrm{Asp} \cdot 2.4 \mathrm{H}_{2} \mathrm{O} \text { for CaHAp-Asp } 10 \\
& \mathrm{Ca}_{10}\left(\mathrm{PO}_{4}\right)_{6}(\mathrm{OH})_{2} \cdot 0.1 \mathrm{Glu} \cdot 1.6 \mathrm{H}_{2} \mathrm{O} \text { for } \mathrm{CaHAp}-\mathrm{Glu}_{1} \\
& \mathrm{Ca}_{10}\left(\mathrm{PO}_{4}\right)_{6}(\mathrm{OH})_{2} \cdot 0.3 \mathrm{Glu} \cdot 1.4 \mathrm{H}_{2} \mathrm{O} \text { for } \mathrm{CaHAp}-\mathrm{Glu}_{5} \\
& \mathrm{Ca}_{10}\left(\mathrm{PO}_{4}\right)_{6}(\mathrm{OH})_{2} \cdot 0.4 \mathrm{Glu} \cdot 2.9 \mathrm{H}_{2} \mathrm{O} \text { for } \mathrm{CaHAp}-\mathrm{Glu}_{10} \text {. }
\end{aligned}
$$

\subsubsection{Structural and morphological characterization}

The X-ray powder diffraction patterns recorded for all the synthesized samples are shown in Figure 2. All the patterns indicate that samples are all single-phase and are composed of crystalline hydroxyapatite (ICSD card No. 99358). CaHAp presents a well crystallized hydroxyapatite phase, as attested by the well resolved diffraction peaks. Nevertheless, the observation of the width of the (002) and (310) diffraction peaks (see indications in Figure 2) reveals an anisotropic coherent domain shape elongated along the hexagonal $c$ axis. The microstructural parameters extracted from Rietveld analyses allow for the quantification of this anisotropy with the ratio $D_{(002)} / D_{(310)}$ (with $D_{(002)}$ being the crystallite size along the 
hexagonal $c$ axis, and $\mathrm{D}_{(310)}$ the crystallite size in the basal $(a, b)$ plane). Structural and microstructural parameters refined from Rietveld refinement are gathered in Table 3. Clearly, the crystallinity is affected by the presence of organic anions that induce a decrease of the coherent domain size (for both anions) combined with an increase of the anisotropy (for glutamate anion).
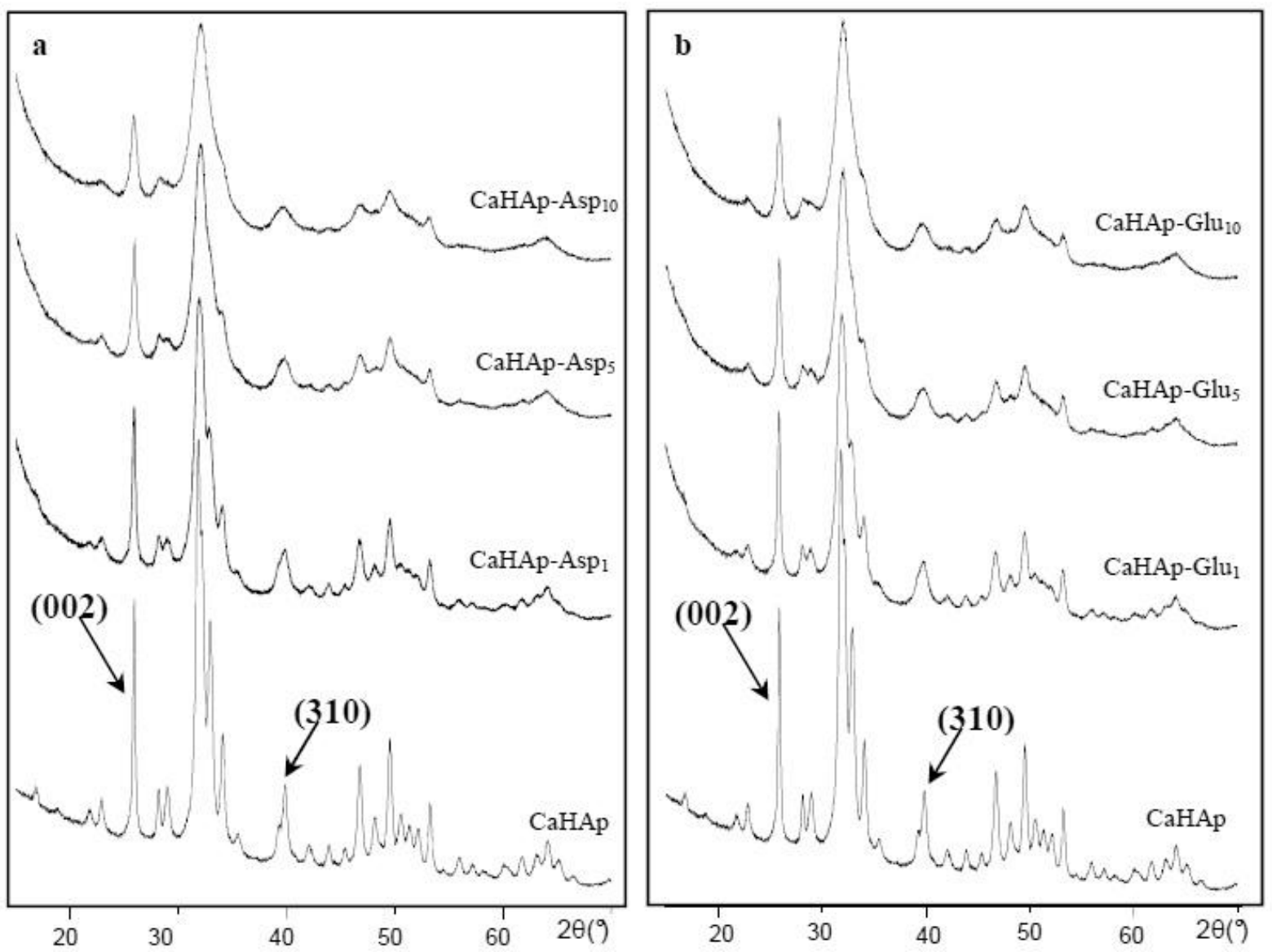

Figure 2. X-ray powder diffraction patterns of: a) CaHAp modified with aspartic acid, b) CaHAp modified with glutamic acid.

Despite the peak broadening due to a deterioration of the crystallinity, the crystal structure of hydroxyapatite is well preserved whatever the amount of organic anions. Lattice parameters increase slightly and continuously with the increasing amount of organic anions for both aspartate and glutamate cases. In hybrid hydroxyapatites, the presence of organic ligands deteriorates the crystallinity and slightly expends the unit cell. This behavior can be attributed 
to the incorporation of organic anions at the surface of small hydroxyapatite domains and/or water incorporation in the structure.

Table 3: Structural and microstructural parameters extracted from Rietveld refinements.

\begin{tabular}{|l|l|l|l|l|l|l|}
\hline \multirow{2}{*}{ Samples } & \multicolumn{3}{l|}{ Lattice parameters } & \multicolumn{3}{l|}{ Coherent domain size } \\
& $a(\AA)$ & $c(\AA)$ & $\mathrm{V}\left(\AA^{3}\right)$ & $\mathrm{D}_{(002)}(\AA)$ & $\mathrm{D}_{(310)}(\AA)$ & $\begin{array}{l}\text { Anisotropy } \\
\mathrm{D}_{(002)} / \mathrm{D}_{(310)}\end{array}$ \\
\hline CaHAp & $9.412(1)$ & $6.878(1)$ & $527.7(2)$ & 310 & 120 & 2.6 \\
\hline CaHAp-Asp $_{1}$ & $9.421(3)$ & $6.881(3)$ & $528.8(3)$ & 220 & 70 & 3.1 \\
CaHAp-Asp $_{5}$ & $9.423(5)$ & $6.886(5)$ & $529.6(5)$ & 180 & 60 & 3.0 \\
CaHAp-Asp $_{10}$ & $9.458(2)$ & $6.894(2)$ & $534.1(3)$ & 130 & 45 & 2.9 \\
\hline CaHAp-Glu $_{1}$ & $9.418(2)$ & $6.880(2)$ & $528.5(2)$ & 240 & 70 & 3.4 \\
CaHAp-Glu $_{5}$ & $9.421(5)$ & $6.887(5)$ & $529.6(5)$ & 190 & 55 & 3.5 \\
CaHAp-Glu $_{10}$ & $9.436(8)$ & $6.890(6)$ & $531.4(8)$ & 150 & 40 & 3.8 \\
\hline
\end{tabular}

SEM micrographs of the three CaHAp, CaHAp-Asp ${ }_{10}$ and CaHAp-Glu ${ }_{10}$ samples are shown in Figure 3. The morphology of the samples is strongly affected by the presence of organic anions in agreement with microstructural parameters extracted from Rietveld refinements. CaHAp powder is composed of largely anisotropic elongated crystals correlated with the refined anisotropy of the average coherent domain size. Isolated crystals are not at all observable for hybrid materials (when using the same magnification) based on the aspartate anion, whereas some are still distinguishable, with difficulty, for glutamate-based hybrid materials. The deterioration of the crystallinity determined from Rietveld refinement agrees with these direct SEM observations.

SSA measured for the different samples show not significant effect of grafting on the SSA.

The SSA of starting raw material (phosphate rock) is quite low around $21 \mathrm{~m}^{2} / \mathrm{g}$, the SSA of the derived apatites is much higher $\left(47 \mathrm{~m}^{2} / \mathrm{g}\right.$ for the pure apatite and slightly lower for the CaHAp-Glu $42 \mathrm{~m}^{2} / \mathrm{g}$ and the CaHAp-Asp $39 \mathrm{~m}^{2} / \mathrm{g}$ ). These values of SSA are reasonably high for providing good interactions of these materials with liquid phases. On the other hand the similarity of valued obtained for the Glu and Asp means that this parameter will not influence 
interpretation of sorption data and this will allow to assess the effect of the nature and concentration of the carboxylic acid.
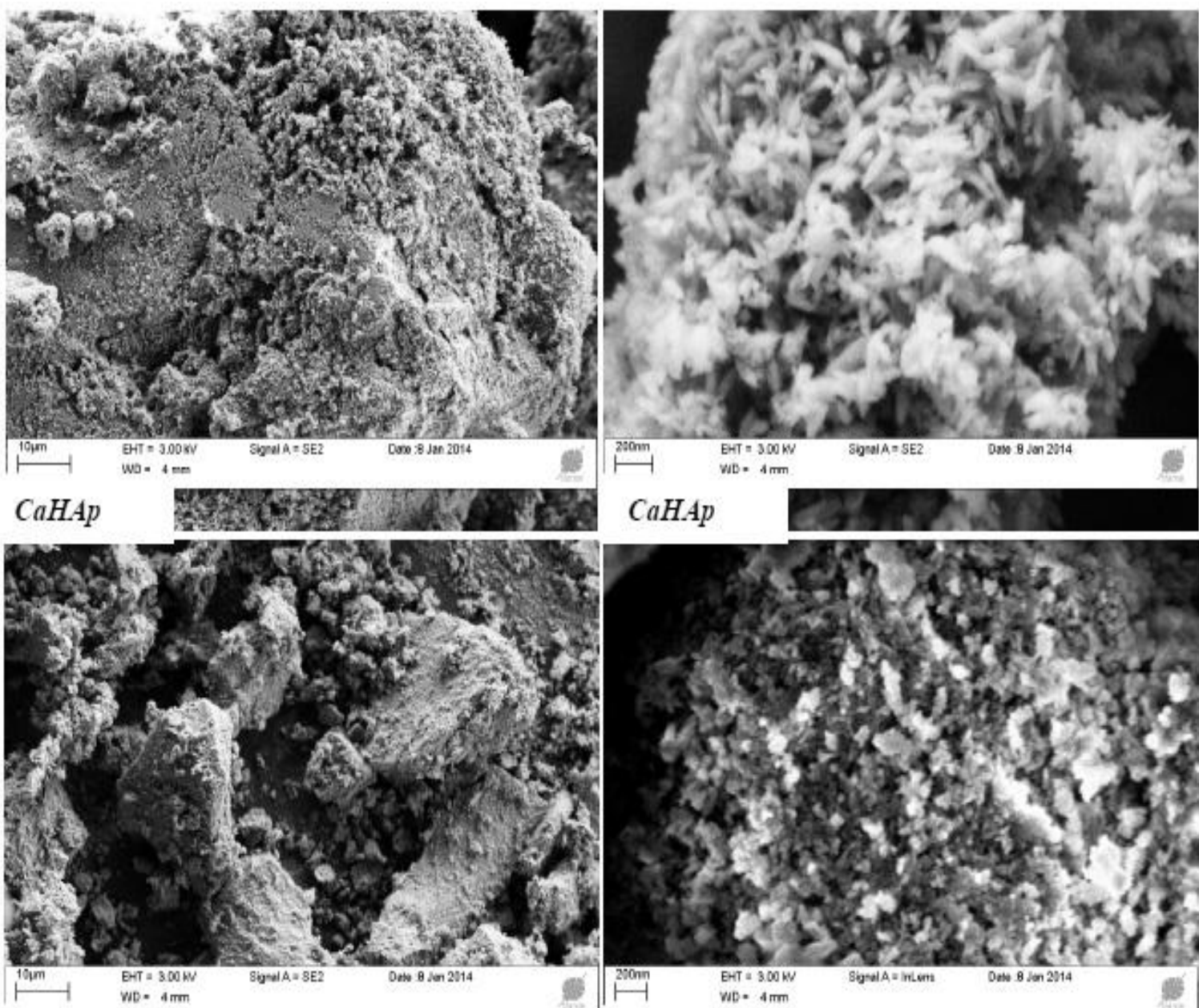

CaHAP
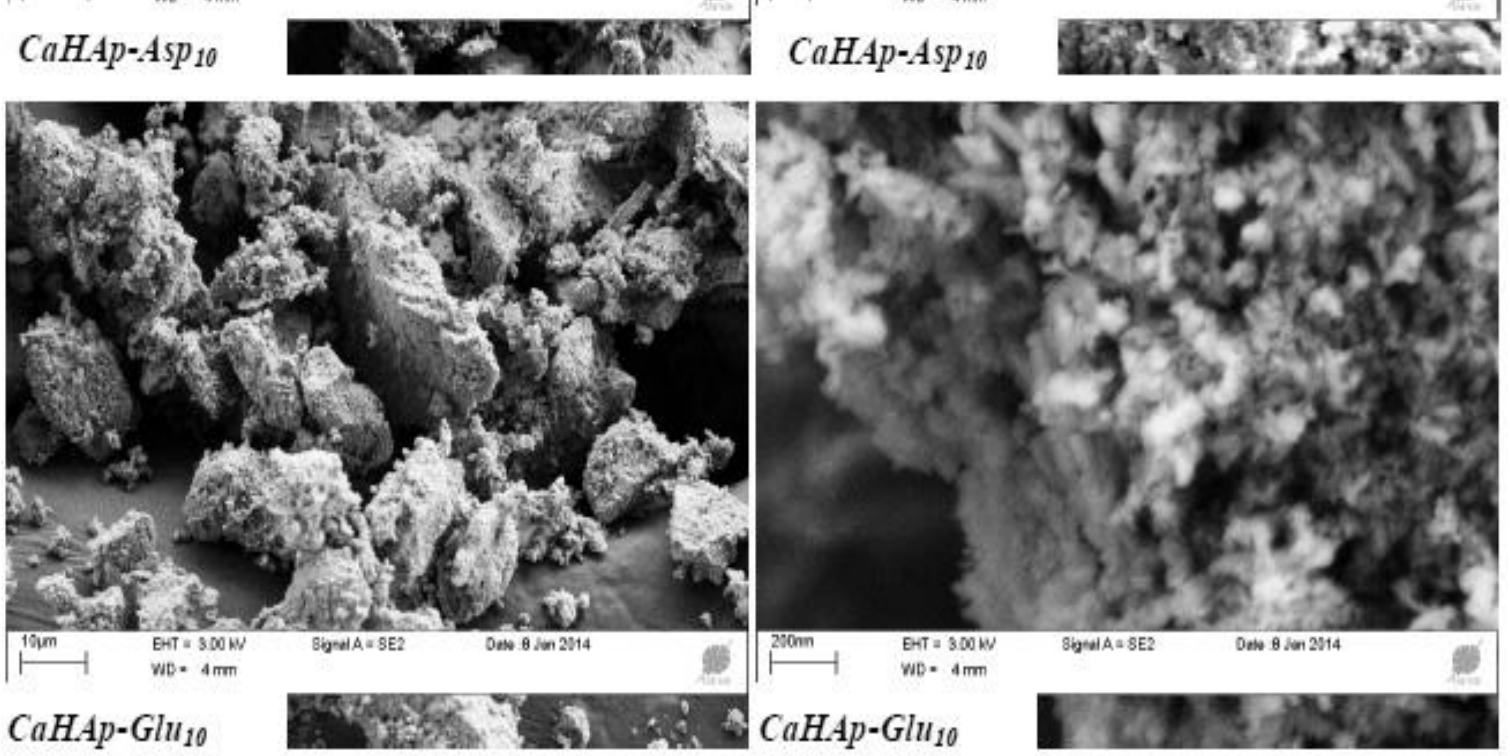

Figure 3. SEM images of CaHAp, CaHAp-Asp 10 and CaHAp-Glu ${ }_{10}$. 


\subsubsection{Grafting mechanism}

The infrared spectra of pure and modified hydroxyapatite, in the presence of variable amounts of glutamate or aspartate anions (displayed in Figure 4), present the vibration bands characteristic of the $\left(\mathrm{PO}_{4}\right)^{3-}$ group: $v_{1}\left(960 \mathrm{~cm}^{-1}\right), v_{2}\left(474 \mathrm{~cm}^{-1}\right), v_{3}\left(1018 \mathrm{~cm}^{-1}, 1090 \mathrm{~cm}^{-1}\right)$, and $v_{4}\left(600 \mathrm{~cm}^{-1}, 560 \mathrm{~cm}^{-1}\right)$. Characteristic vibration of hydroxyl ions is observed towards 3565 $\mathrm{cm}^{-1}$ for CaHAp. The band observed at $1420 \mathrm{~cm}^{-1}$ is attributed to the presence of carbonate ions in the inorganic CaHAp sample $\mathrm{e}^{35-37}$. Hybrid hydroxyapatite samples prepared in the presence of aspartic acid and glutamic acid present two new bands centered at $1413 \mathrm{~cm}^{-1}$ and $1567 \mathrm{~cm}^{-1}$, and centered at $1423 \mathrm{~cm}^{-1}$ and $1576 \mathrm{~cm}^{-1}$ for the glutamate and aspartate samples respectively. This doublet is attributed to the symmetric and the asymmetric ( $v_{\mathrm{s}}$ and $v_{\mathrm{as}}$ ) elongation of the carboxylate $\left(\mathrm{COO}^{-}\right)$function. Their intensities increase with the amount of organic acid incorporated during the synthesis, indicating an increase in the amount ${ }^{9,38}$ of grafted organic anions in agreement with chemical analyses (Table 1). For both organic anions, the splitting between $v_{\mathrm{as}}$ and $v_{\mathrm{s}}$ is about $155 \mathrm{~cm}^{-1}$ but with a shift of about $10 \mathrm{~cm}^{-1}$ toward smaller wavenumbers for both $v_{\mathrm{as}}$ and $v_{\mathrm{s}}$ vibrations for the glutamate anion; potentially indicating two different grafting strengths. $\Delta v$ values around $150 \mathrm{~cm}^{-1}$ agree with the unidentate character of the carboxylate function engaged in the hydrogen bond. ${ }^{39}$ Different possible grafting mechanisms are shown in Scheme 1. 


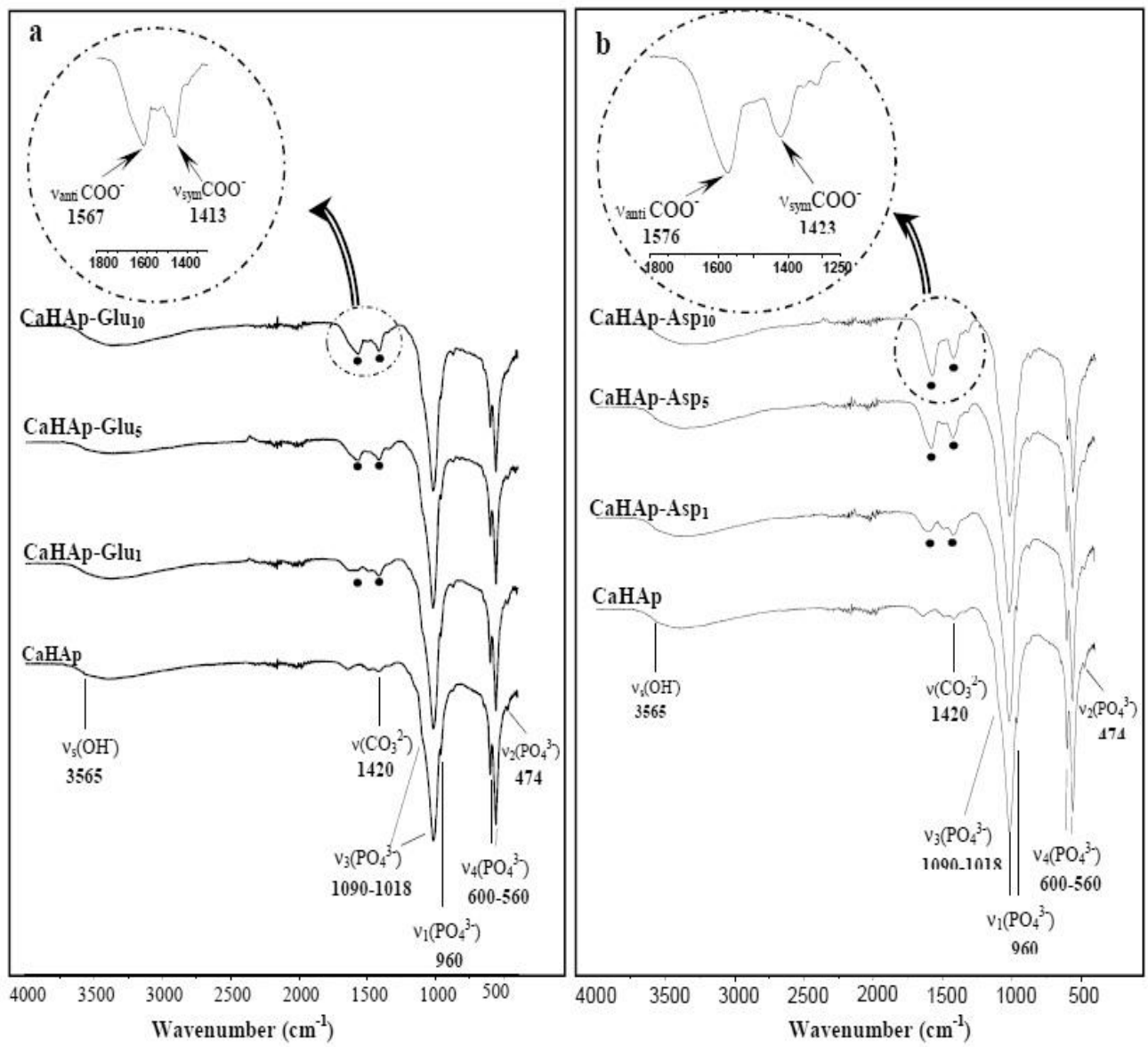

Figure 4. IR absorption spectra of CaHAp sample compared to CaHAp-Glu samples (a), and CaHAp-Asp samples (b).

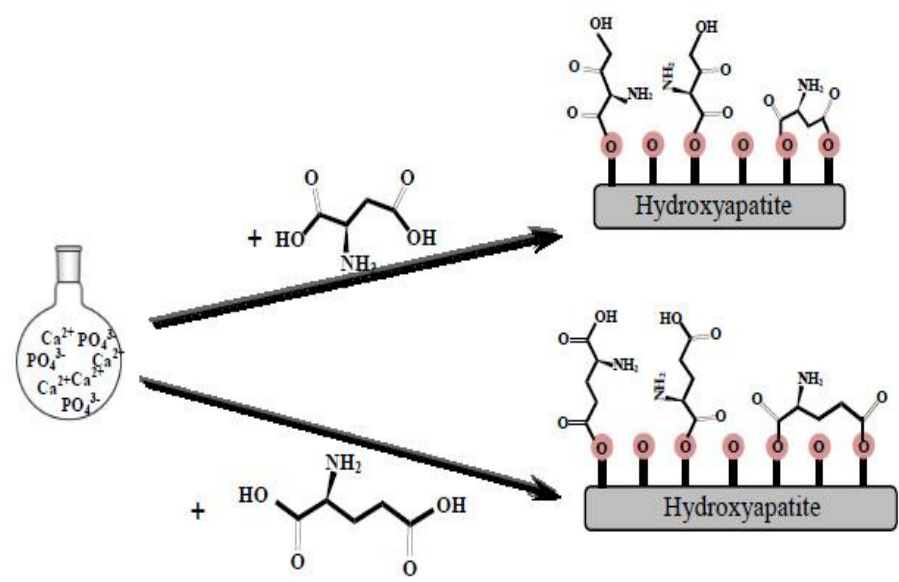

Scheme 1. Proposed grafting mechanisms for Glutamate and Aspartate anions on the CaHAp surface.

\subsubsection{Solid-state NMR spectroscopy}




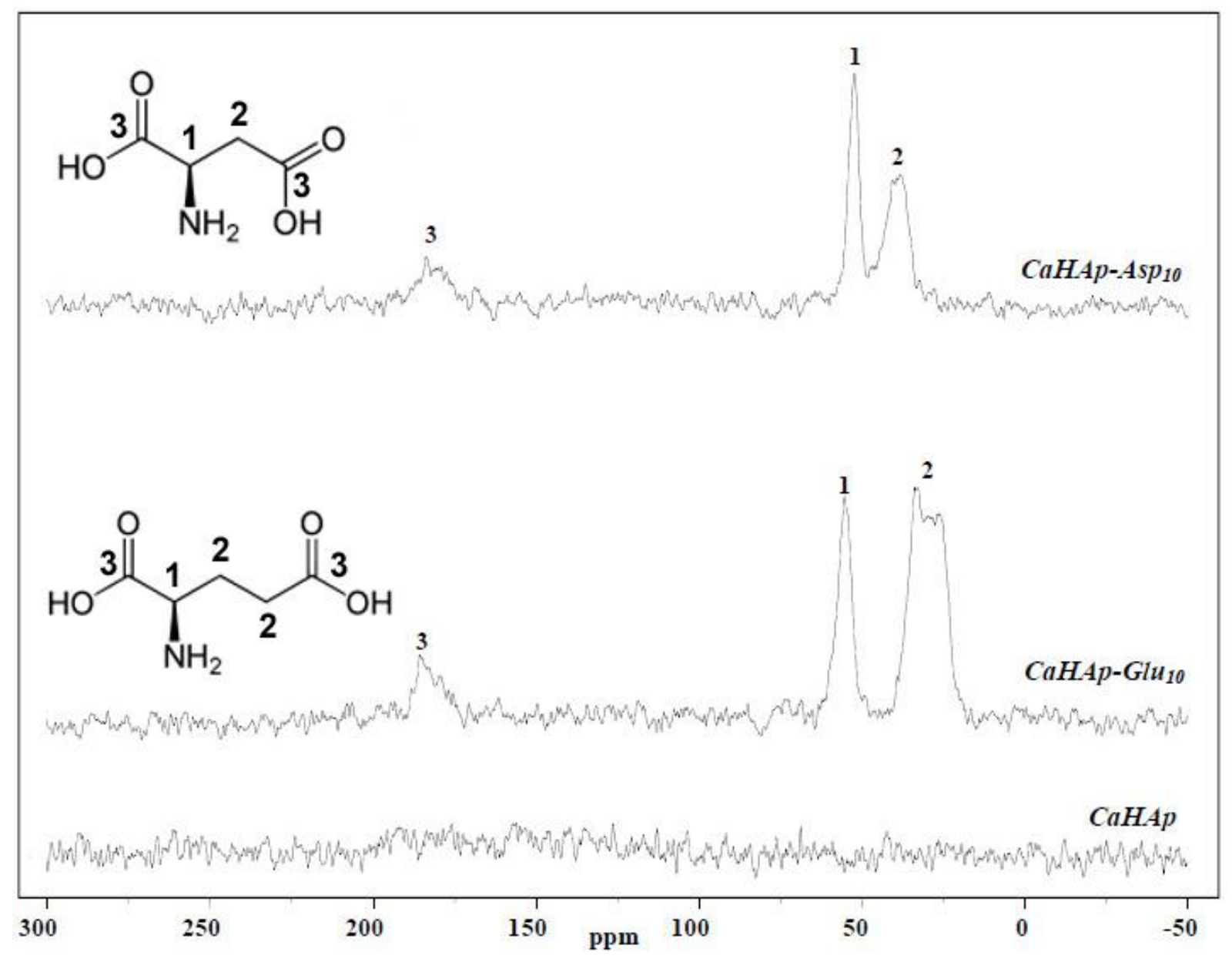

Figure 5. ${ }^{13} \mathrm{C}$ CP-MAS NMR spectra of $\mathrm{Ca}_{10} \mathrm{HAp}$ prepared from TPR without and with Glutamic acid and Aspartic acid

The ${ }^{13} \mathrm{C}$ CP-MAS spectra of the pure hydroxyapatite CaHAp and of the two grafted compounds (CaHAp-Asp $\left.{ }_{10}\right)$ and $\left(\mathrm{CaHAp}-\mathrm{Glu}_{10}\right)$ are shown in Figure 5. As expected, the inorganic CaHAp sample did not present the ${ }^{13} \mathrm{C}$ signal; indicating that carbonate contamination is low, in agreement with chemical analyses (Table 1). The spectra of grafted samples evidence the presence of organic anions in the samples by the presence of three distinct ${ }^{13} \mathrm{C}$ signals. Two intense and resolved peaks around 40 and $60 \mathrm{ppm}$, and a third less intense and broadened signal at $180 \mathrm{ppm}$. The two resolved signals are attributed to the carbon atom from $\mathrm{CH}_{2}(\sim 40 \mathrm{ppm}$, with multiple contributions in the case of glutamate anion because of the presence of two $\mathrm{CH}_{2}$ groups) and $\mathrm{CH}(\sim 60 \mathrm{ppm})$ groups, whereas the broadened signal corresponds to carbon atoms from the carboxylate function $\left(\mathrm{COO}^{-}\right)^{40-41}$. In 
the spectrum of the CaHAp-Asp 10 sample, the broadened signal from carboxylate is rather symmetric, indicating that the two carboxylate functions are equivalent in the hybrid material; i.e. indicating that the two carboxylate functions are involved, without distinction, in the grafting mechanism. This broadened ${ }^{13} \mathrm{C}$ signal is slightly more asymmetric in the case of CaHAp-Glu ${ }_{10}$, indicating that for this hybrid one carboxylate function preferentially interacts in the grafting mechanism. These two different situations may explain the difference in the loading of the organic molecule.

\section{2. $\mathrm{Pb}^{2+}$ sorption isotherms}

\subsubsection{Sorption kinetic}

The adsorption of $\mathrm{Pb}^{2+}$ by CaHAp, CaHAp-Asp 10 and CaHAp-Glu 10 was measured over a period of 4 hours for three initial $\mathrm{Pb}^{2+}$ concentrations $(1,2$ and $4 \mathrm{mmol} / \mathrm{L})$. The initial $\mathrm{pH}$ of the lead solution was $\mathrm{pH}=5$. After contacting the powders with the solution the $\mathrm{pH}$ decreases slightly around 4.2, the $\mathrm{pH}$ then increases up to 4.6 for HAp, 4.8 for HAp-Glu and 5 for HApAsp upon time (see supplementary Figure S3).

Figure 6 presents the kinetic of adsorption for the three materials. The calculation of $q_{a}$ values is explained in section 2.3. The presence of grafted organic anions improves the $\mathrm{Pb}^{2+}$ sorption in terms of quantities adsorbed and in terms of kinetic. For the two lower $\mathrm{Pb}^{2+}$ concentrations the same values of $q_{a}$ are reached for the inorganic CaHAp and the two hybrid hydroxyapatites; i.e. $q_{a} \sim 0.5 \mathrm{mmol} / \mathrm{g}$ for $\left[\mathrm{Pb}^{2+}\right]=1 \mathrm{mmol} / \mathrm{L}$ and $q_{a} \sim 1.0 \mathrm{mmol} / \mathrm{g}$ for $\left[\mathrm{Pb}^{2+}\right]=$ $2 \mathrm{mmol} / \mathrm{L}$. For the more concentrated solution with $\left[\mathrm{Pb}^{2+}\right]=4 \mathrm{mmol} / \mathrm{L}$, the $q_{a}$ value obtained is higher for the two hybrid materials: approx. $2.0 \mathrm{mmol} / \mathrm{g}$ for CaHAp-Asp 10 and CaHAp$\mathrm{Glu}_{10}$ (which almost corresponds to $100 \%$ of $\mathrm{Pb}^{2+}$ removal) compared to about $1.8 \mathrm{mmol} / \mathrm{g}$ for CaHAp (see Table 4). The sorption kinetic is also improved by the presence of the grafted organic anions. The equilibrium is reached only after 120 minutes for the CaHAp sample, 
whereas it is already reached at 15 minutes for both the CaHAp-Asp ${ }_{10}$ and CaHAp-Glu 10 samples.
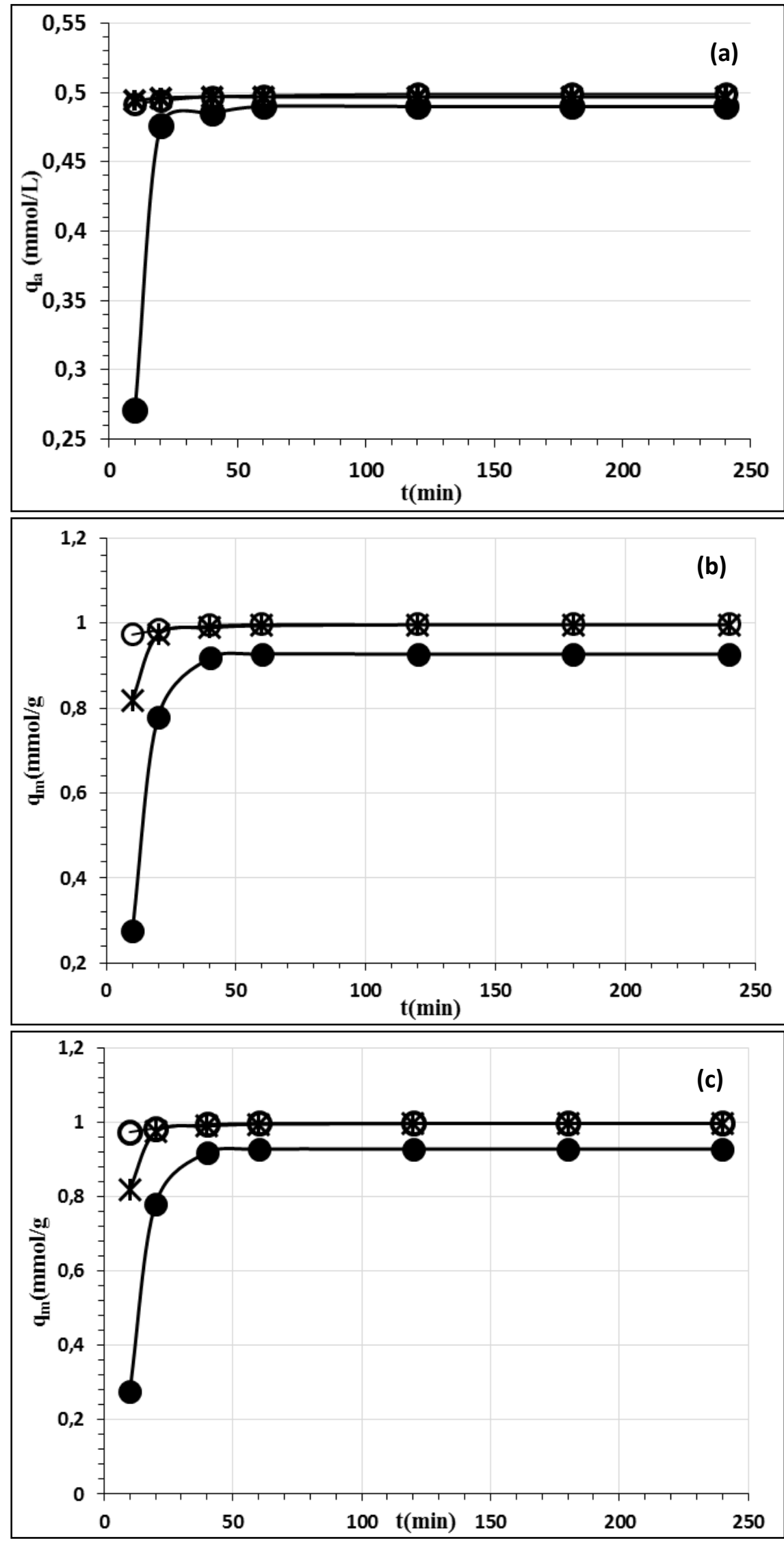


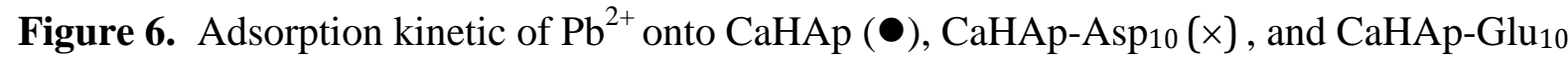
(O) for various inital concentrations $1 \mathrm{mmol}$ (a), $2 \mathrm{mmol}$ (b) and $4 \mathrm{mmol}$ (c).

Table 4. Adsorption capacities for CaHAp, CaHAp-Asp 10 and CaHAp-Glu $10\left(\left[\mathrm{~Pb}^{2+}\right]_{0}=4 \mathrm{mmol} / \mathrm{L}\right.$ and $\mathrm{t}=3 \mathrm{~h}$ )

\begin{tabular}{|l|l|l|}
\hline Adsorbents & $q_{a}(\mathrm{mmol} / \mathrm{g})$ & $\mathrm{Pb}^{2+}(\%)$ \\
\hline CaHAp & 1.806 & 90.30 \\
\hline CaHAp-Asp 10 & 1.985 & 99.20 \\
\hline CaHAp-Glu $_{10}$ & 1,992 & 99.60 \\
\hline
\end{tabular}

\subsubsection{Adsorption isotherm}

Having determined the appropriate equilibration time for sorption, adsorption isotherms can now be determined. Measurements were performed at $\mathrm{T}=25^{\circ} \mathrm{C}$ and $\mathrm{pH}=5$ with a 3-hour equilibration time. Figure 7 illustrates the effect of the initial concentration on the $\mathrm{Pb}^{2+}$ ions' adsorption in aqueous solution. Adsorption isotherms evidence the improvement of sorption properties for hybrid material, as already mentioned. A higher amount of $\mathrm{Pb}^{2+}$ removal is achieved with CaHAp-Asp 10 and CaHAp-Glu G $_{10}$, and saturation is also achieved for a lower initial $\mathrm{Pb}^{2+}$ concentration, indicating a higher efficiency of surface sites for hybrid hydroxyapatites. The three adsorption isotherms are of L-type according to the classification of Gilles et al. ${ }^{42}$. This suggests that the sorption process does not only involve ion-exchange reactions, but can also occur through surface dissolution, surface adsorption and precipitation $^{43}$. The presence of structural channels could also contribute to cationic fixation.

The measured sorption isotherms have been modeled by the two Freundlich and Langmuir models. The Freundlich adsorption isotherm model is the earliest known relationship describing the sorption equilibrium according to equation $(2)^{44}$ where $q_{a}$ is the adsorbed quantity on the solid phase ( $\mathrm{mmol} / \mathrm{g}), C_{e}$ is the equilibrium concentration in the liquid phase 
$(\mathrm{mmol} / \mathrm{g}), K_{f}(\mathrm{mg} / \mathrm{g})$ and $n_{f}$ are isotherm parameters characteristic of adsorption capacity and absorption intensity $^{45,46}$, respectively. Linearization of eq. (2) leads to eq. (3), which was used for the fitting procedure (Figure S1).

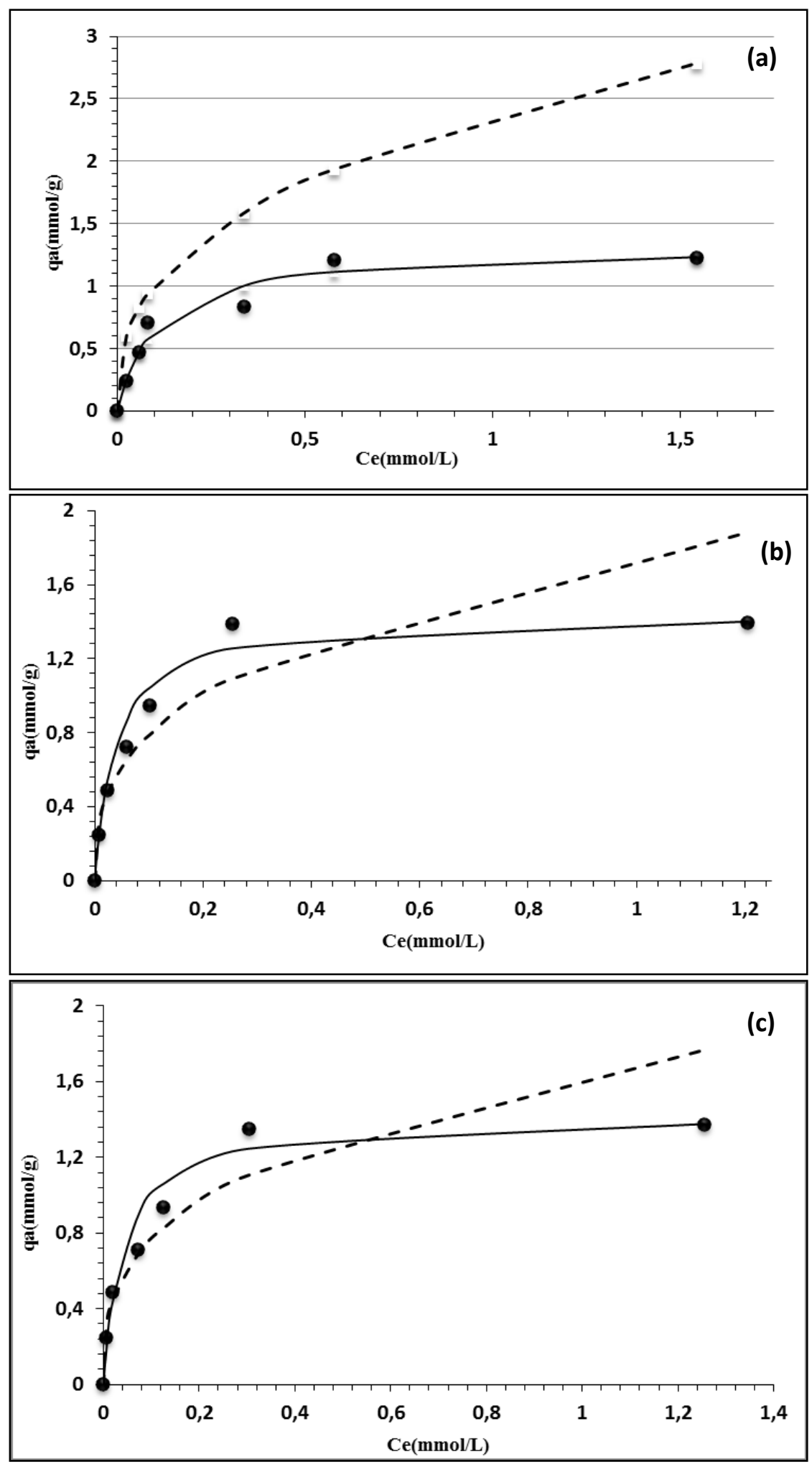


Figure 7. Adsorption isotherms (Circles) of $\mathrm{Pb}^{2+}$ onto CaHAp (a), CaHAp-Asp 10 (b) and CaHAp-Glu ${ }_{10}$ (c) samples together with Langmuir fits (continuous lines) and Freundlich fits (dotted lines).

$$
\begin{gathered}
q_{a}=K_{f} C_{e}^{1 / n_{f}} \\
\operatorname{Ln}\left(q_{a}\right)=\operatorname{Ln}\left(K_{f}\right)+1 / n_{f} \operatorname{Ln}\left(C_{e}\right)
\end{gathered}
$$

The Freundlich adsorption isotherm describes the adsorption characteristics for a heterogeneous surface. A linear regression has been used to fit Freundlich isotherm parameters using equation (3) (Figure 7 (squares)). The refined parameters are summarized in Table 5. The three sorbents present similar $1 / n_{f}$ values around 0.35 indicating a normal adsorption mechanism $\left(1 / n_{f}<1\right)$ with similar surface heterogeneity for the mineral hydroxyapatite CaHAp and for the two hybrid hydroxyapatites. The $K_{f}$ parameter indicates the adsorption capacity of the system studied. This value is smaller for CaHAp $(1.77 \mathrm{mg} / \mathrm{g})$ than for the hybrid systems (around $3.5 \mathrm{mg} / \mathrm{g}$ ) in agreement with the higher adsorbed amount for CaHAp-Asp 10 and CaHAp-Glu ${ }_{10}$.

The Langmuir isotherm is widely used to model the adsorption of heavy metals in aqueous solution on a solid surface. It describes quantitatively the formation of a monolayer of adsorbate on the outer surface of the adsorbent. The Langmuir model represents the equilibrium distribution of metal ions between the solid and the liquid phases, assuming that the surface contains a finite number of identical sites (homogeneous surface with uniform energies of adsorption). The Langmuir model is described by equation (4), and its linearization leads to equation $(5)^{47}$ :

$$
q_{a}=q_{m} \frac{K_{l} C_{e}}{1+K_{l} C_{e}}
$$




$$
\frac{C_{e}}{q_{a}}=\frac{1}{K_{l} q_{m}}+\frac{C_{e}}{q_{m}}
$$

where $q_{a}$ is the equilibrium adsorption capacity of adsorbent ( $\left.\mathrm{mmol} / \mathrm{g}\right), C_{e}$ is the equilibrium concentration of the metal ions $(\mathrm{mmol} / \mathrm{L}), q_{m}$ is the maximum amount of metal ions adsorbed (mmol/g), and $K_{l}$ is the Langmuir constant that refers to the bonding energy of the adsorption mechanism $(\mathrm{L} / \mathrm{mmol})$. The $K_{l}$ and $q_{m}$ values can be determined by least square linear regression of eq. (5) (Figure S2). The experimental data fits very well with the Langmuir model (Figure 7 (triangles)). The refined parameters (Table 5) indicate the improvement brought about by organic anions. The $q_{m}$ value is increased from $1.32 \mathrm{mmol} / \mathrm{g}$ for the inorganic CaHAp system to about $1.43 \mathrm{mmol} / \mathrm{g}$ for the two hybrid systems. On the other hand, the $K_{l}$ value increases considerably from about $10 \mathrm{~L} / \mathrm{mmol}$ for CaHAp to about 50 L/mmol for the hybrid systems. The best adsorption results were obtained for the CaHAp$\mathrm{Asp}_{10}$ system that presents the highest bonding energy between $\mathrm{Pb}^{2+}$ and the hybrid hydroxyapatite surface.

Clearly the Langmuir model better represents the experimental data for the three materials (with or without grafted organic anions at the hydroxyapatite surface). This indicates a homogeneous surface with one kind of active site for $\mathrm{Pb}^{2+}$ remediation. The homogeneity is valuable for the three solids, but sites are more active in the presence of grafted aspartate and glutamate anions. The bonding energy is higher in the case of the aspartate anion, certainly in relation with its more efficient grafting process. Indeed the CaHAp-Asp ${ }_{10}$ sample contains 0.6 organic anions per $\mathrm{Ca}_{10}\left(\mathrm{PO}_{4}\right)_{6}(\mathrm{OH})_{2}$, whereas CaHAp-Glu 10 sample contains 0.4 glutamate anion per $\mathrm{Ca}_{10}\left(\mathrm{PO}_{4}\right)_{6}(\mathrm{OH})_{2}$. These preliminary results should be completed by more detailed analyses including selectivity experiments as well as trace experiments. 
Table 5. Freundlich and Langmuir constants and correlation coefficients for the adsorption of $\mathrm{Pb}^{2+}$ on CaHAp, CaHAp-Asp 10 and CaHAp-Glu $\mathrm{G}_{10}$.

\begin{tabular}{|c|c|c|c|c|c|c|}
\hline \multirow[b]{2}{*}{ Adsorbent } & \multicolumn{3}{|c|}{ Freundlich } & \multicolumn{3}{|c|}{ Langmuir } \\
\hline & $\begin{array}{l}K_{f} \\
(\mathrm{mg} / \mathrm{g})\end{array}$ & $1 / n_{f}$ & $R^{2}$ & $\begin{array}{l}q_{m} \\
(\mathrm{mmol} / \mathrm{g})\end{array}$ & $\begin{array}{l}K_{l} \\
(\mathrm{~L} / \mathrm{mmol})\end{array}$ & $R^{2}$ \\
\hline CaHAp & 1.766 & 0.370 & 0,862 & 1.316 & 9.500 & 0.992 \\
\hline $\mathrm{CaHAp} \mathrm{Asp} \mathrm{p}_{10}$ & 3.707 & 0.350 & 0.893 & 1.449 & 51.750 & 0.998 \\
\hline CaHAp-Glu 10 & 3.126 & 0.330 & 0.920 & 1.426 & 44.020 & 0.998 \\
\hline
\end{tabular}

\section{CONCLUSION}

Single-phase hydroxyapatite samples have been synthesized from natural Tunisian Phosphate Rock (TPR), using a dissolution-reprecipitation method. The introduction of organic acids (aspartic and glutamic acids) led to the precipitation in basic $\mathrm{pH}$ of hybrid hydroxyapatite samples with the organic anions (aspartate and glutamate anions) grafted at the hydroxyapatite surface. The crystallinity of hydroxyapatite is affected by the presence of an organic-inorganic interface for both hybrid materials. Rietveld refinements of XRPD patterns evidence an increase in lattice parameters with a concomitant decrease of average coherent domain size. Nevertheless, the apatitic structure of the material is preserved. SEM observations also demonstrate the crystallinity deterioration for the hybrid hydroxyapatite samples as compared to the purely inorganic hydroxyapatite sample. The amount of aspartate anions incorporated at the inorganic surface is higher than for the glutamate anion; about 0.6 
aspartate anions to 0.4 glutamate anions per $\mathrm{Ca}_{10}\left(\mathrm{PO}_{4}\right)_{6}(\mathrm{OH})_{2}$ motif. Chemical analyses and TGAs converge to these quantitative estimations, and the TGAs also indicate the presence of large amounts of physisorbed water molecules at the organic-inorganic interface (about 2 molecules of water per $\mathrm{Ca}_{10}\left(\mathrm{PO}_{4}\right)_{6}(\mathrm{OH})_{2}$ motif). The incorporation mechanism seems to be different for the two organic anions studied according to ${ }^{13} \mathrm{C}$ NMR and FTIR spectroscopies, with the two carboxylate functions involved for aspartate contrary to glutamate. The prepared materials have been tested for aqueous $\mathrm{Pb}^{2+}$ remediation. The $\mathrm{Pb}^{2+}$ sorption is improved for hybrid hydroxyapatite in comparison with the inorganic hydroxyapatite: the sorption capacity and the adsorption kinetic are both increased. Modeling of the sorption isotherms, considering Freundlich and Langmuir equations, have shown that samples present a homogeneous surface with one single active site for $\mathrm{Pb}^{2+}$ remediation. The bonding energy at this site is considerably increased in the presence of grafted organic anions. The best result is obtained for the aspartate hybrid hydroxyapatite, probably because of the higher amount of grafted organic anions and/or because of the different grafting mechanism.

\section{ACKNOWLEDGMENTS}

We are thankful to the Gafsa Phosphates Company (GPC-CPG) for providing the natural phosphate rock investigated. The (NIRPA-INRAP) National Institute of Research and Physicochemical Analysis, the Research and Technology Centre of Borj Cedria and the University of Monastir (Tunisia) are acknowledged for their financial support.

\section{REFERENCES}


(1) McClellan, G.H.; Kauwenbergh, S.; Van, J.; Mineralogy of sedimentary apatites. Geol. Soc. Lond. 1990, 52, 23-31.

(2) Bachoua, H.; Othmani, M.; Coppel, Y.; Fatteh, N.; Debbabi, M.; Badraoui, B. Structural and thermal investigations of a Tunisian natural phosphate rock. J. Mater. Environ. Sci. 2014, $5,1152-1159$.

(3) Chaabouni, A.; Chtara, C.; Nzihou, A.; El Feki, H. Study the effects of calcinations and evolution of crystallographic parameters of two Tunisian natural phosphates. Journal of Advances in Chemistry. 2013, 6, 908-916.

(4) Bigi, A.; Gazzano, M.; Ripamonti, A.; Foresti, E.; Roveri, N. Thermal stability of cadmium-calcium hydroxyapatite solid solutions. Journal of Chemistry Society Dalton Transactions 1986, 2, 241-244.

(5) Tsuchida, T.; Yoshioka, T.; Sakuma, S.; Takeguchi, T.; Ueda, W. Synthesis of Biogasoline from Ethanol over Hydroxyapatite Catalyst. Ind. Eng. Chem. Res. 2008, 47, 1443-1452.

(6) Al-Kattan, A.; Errassifi, F.; Sautereau, A.M.; Sarda, S.; Dufour, P.; Barroug, A.; Dos Santos, I.; Combes, C.; Grossin, D.; Rey, C.; Drouet, C. Medical Potentialities of Biomimetic Apatites through Adsorption, Ionic Substitution, and Mineral/Organic Associations: Three Illustrative Examples. Advanced Engineering Materials. 2010, 12, 224-233.

(7) Saoiabi, S.; Asri, S.E.L; Laghzizil, A.; Coradin, T.; Lahlil, K. Nanoporous surface of organofunctionalized hydroxyapatite fabricated from natural phosphate rock. Materials Letters. 2010, 64, 2679-2681.

(8) Saoiabi S, El Asri S., Laghzizil A., Saoiabi A., Ackerman J.L., Coradin T. Lead and zinc removal from aqueous solutions by aminotriphosphonate-modified converted natural phosphates. Chemical Engineering Journal 2012, 211-212, 233-239. 
(9) Boanini, E.; Torricelli, P.; Gazzano, M.; Giardino, R.; Bigi, A. Nanocomposites of hydroxyapatite with aspartic acid and glutamic acid and their interaction with osteoblast-like cells. Biomaterials. 2006, 27, 4428-4433.

(10) Aissa, A.; Debbabi, M.; Gruselle, M.; Thouvenot, R.; Gredin, P.; Traksmaa, R.; Tonsuaadu, K. Covalent modification of calcium hydroxyapatite surface by grafting phenyl phosphonate moieties. Journal of Solid State Chemistry. 2007, 180, 2273-2278.

(11) M. Subirade, A. Leubugle, Étude d'une liaison minéral-organique entre un phosphate de calcium et un monomère phosphoryle (On the study of a mineral-organic interface between a calcium phosphate and a phosphorylated monomer). Annales de Chimie France. 1993, 18,183-193.

(12) Zahouily, M.; Charki, H.; Abrouki, Y.; Mounir, B.; Bahlaouan, B.; Rayadh, A.; Sebti, S. Natural Phosphate Modified with Sodium Nitrate: New Efficient Catalyst for the Construction of a Carbon-Sulfur and Carbon-Nitrogen Bonds. Lett. In Org. Chemistry. 2005, 2, 354-359.

(13) Liu, Q.; de Wijn, J.R.; de Groot, K.; Van Blitterswijk, C.A. Sur-face modification of nano-apatite by grafting organic polymer. Biomaterials. 1998, 19, 1067-1072.

(14) Othmani, M.; Aissa, A.; Bachoua, H.; Debbabi, M. Surface modification of calciumcopper hydroxyapatites using polyaspartic acid. Applied Surface Science, 2013, 264, 886-891. (15) Turki, T.; Othmani, M.; Bac, C. G.; Rachdi, F.; Bouzouita, K. Surface modification of zinc-containing hydroxyapatite by tartaric acid. Applied Surface Science. 2013, 284, 66-71.

(16) Agougui, H.; Aissa, A.; Maggi, S.; Debbabi, M. Phosphonate-hydroxyapatite hybrid compounds prepared by hydrothermal method. Applied Surface Science. 2010, 257, 13771382.

(17) Cao, X.; Ma, L.Q.; Singh, S.P.; Zhou, O. Phosphate-induced lead immobilization from different lead minerals in soils under varying pH conditions, Environ. Pollut. 2008, 152, 184192. 
(18) Suzuki, T.; Ishigaki, K.; Ayuzawa, N. Removal of toxic $\mathrm{Pb}^{2+}$ ions by synthetic hydroxyapatites, Chem. Eng. Commun. 1985, 34, 143-151.

(19) Ma, Q.Y.; Traina, S.J.; Logan, T.J.; Ryan, J.A. In situ lead immobilization by apatite, Environ. Sci. Technol. 1993, 27, 1803-1810.

(20) Knox, A.S.; Kaplan, D.I.; Paller, M.H. Phosphate sources and their suitability for remediation of contaminated soils, Sci. Tot. Environ. 2006, 357, 271-279.

(21) Manecki, M.; Maurice, P.A.; Traina, S.J. Kinetics of aqueous Pb reaction with apatites, Soil Sci. 2000, 165, 920-933.

(22) Baillez, S.; Nzihou, A.; Bernache-Assolant, D.; Champion, E.; Sharrock, P. Removal of aqueous lead ions by hydroxyapatites: equilibria and kinetic processes, J. Hazard. Mater. 2007, 139, 443-446.

(23) Perdikatsis, B. X-ray powder diffraction study of francolite by the Rietveld method, Materials Science Forum. 1991, 79, 809-814.

(24) Conca, J.L. Phosphate-Induced Metal Stabilization (PIMS), Final Report to the U.S. Environmental Protection Agency \#68D60023, U.S. Environmental Protection Agency, Research Triangle Park, 1997.

(25) Conca, J.L.; Wright, J. An apatite II permeable reactive barrier to remediate groundwater containing Zn, $\mathrm{Pb}$ and Cd, Appl. Geochem. 2006, 21, 1288-1300.

(26) Ma, Q.Y.; Logan, T.J.; Traina, S.J. Lead immobilization from aqueous solutions and contaminated soils using phosphate rocks, Environ. Sci. Technol. 1995, 29, 1118-1126.

(27) Ma, L.Q.; Choate, A.L.; Rao, G.N. Effects of incubation and phosphate rock on lead extractability and speciation in contaminated soils, J. Environ. Qual. 1997, 26, 801-807.

(28) Singh, S.P.; Ma, L.Q.; Harris, W.G. Heavy metal interactions with phosphatic clay: sorption and desorption behavior, J. Environ. Qual. 2001, 30, 1961-1968. 
(29) El Asri, S.; Laghzizil, A.; Saoiabi, A.; Alaoui, A.; El Abassi, K.; M'hamdi, R.; Coradin, T. A novel process for the fabrication of nanoporous apatites from Moroccan phosphate rock. Colloids and Surfaces A: Physicochem. Eng. Aspects 2009, 350, 73-78.

(30) Gee, A.; Deitz U. R. Determination of Phosphate by Differential Spectrophotometry. Anal Chem, 1953, 25, 1320-1324.

(31) Rietveld, H. M. A profile refinement method for nuclear and magnetic structures. Journal of Applied Crystallography, 1969, 2, 65-71.

(32) Carvajal, R. J. Satellite meeting on powder diffraction of the XV congress of the IUCr. Book of Abstracts, Toulouse, France, 1990, 127.

(33) Zheng, W.; Li, X.M.; Yang, Q.; Zeng, G.M.; Shen, X.X.; Zhang, Y.; Liu, J.J. Adsorption of $\mathrm{Cd}(\mathrm{II})$ and $\mathrm{Cu}(\mathrm{II})$ from aqueous solution by carbonate hydroxyapatite derived from eggshell waste, J. Hazard. Mater. 2007, 147, 534-539.

(34) Parthiban, S. P.; Elayaraja, K.; Girija, E. K.; Yokogawa, Y.; Kesavamoorthy, R.; Palanichamy, M.; Asokan, K.; Narayana, K. S. Preparation of thermally stable nanocrystalline hydroxyapatite by hydrothermal method. J Mater Sci: Mater Med, 2009, 20, $77-83$

(35) Rehman, I.; Bonfield, W. Characterization of hydroxyapatite and carbonated apatite by photo acoustic FTIR spectroscopy. Journal of materials science: materials in Medicine, 1997, $8,1-4$

(36) Fleet, M.; Lin, X. Carbonate apatite type A synthesized at high pressure: new space group (P3) and orientation of channel carbonate ion. Journal of Solid State Chemistry. 2003, $174,412-417$.

(37) Perrone, J.; Fourest, B.; Giffaut, E. Surface Characterization of Synthetic and Mineral Carbonate Fluoroapatites. Journal of Colloid and Interface Science. 2002, 249, 441-452 
(38) Barth, A. The infrared absorption of amino acid side chains Progress in Biophysics \& Molecular Biology. 2000, 74, 141-173.

(39) Poul, L.; Jouini, N.; Fievet, F. Layered hydroxide metal acetates (metal = zinc, cobalt, and nickel) : elaboration via hydrolysis in polyol medium and comparative study, Chem. Mat. 2000, 12, 3123-3132.

(40) Ikawa, N.; Kimura, T.; Oumi, Y.; Sano, T. Amino acid containing amorphous calcium phosphates and the rapid transformation into apatite. J. Mater. Chem. 2009, 19, 4906-4913.

(41) Othmani, M.; Aissa, A.; GozeBac, C.; Rachdi, F.; Debbabi, M. Surface modification of calcium hydroxyapatite by grafting of etidronic acid. Applied Surface Science. 2013, 274, $151-157$

(42) Giles, C.H.; Smith, D.; Huitson, A.; A general treatment and classification of the solute adsorption isotherm. I. Theoretical, J. Colloid. Interf. Sci. 1974, 47, 755-765.

(43) Jang, S.H.; Min, B.G.; Jeong, Y.G.; Lyoo, W.S.; Lee, S.C. Removal of lead ions in aqueous solution by hydroxyapatite/polyurethane composite foams, J. Hazard.Mater. 2008, $152,1285-1292$.

(44) Freundlich, H.M.F. Over the adsorption in solution, J. Phys. Chem. 1906, 57385-470

(45) Malkoc, E.; Nuhoglu, Y. The removal of chromium (VI) From synthetic wastewater by Ulothrix zonata, Fresenius Environ. Bull. 2003, 12, 376-381.

(46) Kadirvelu, K.; Thamarai S. K.; Namasivayam, C.; Adsorption of nickel (II) from aqueous solution onto activated carbon prepared from coirpith, Sep. Purif. Technol. 2001, 24, 497-505. (47) Langmuir I.; The constitution and fundamental properties of solids and liquids. Part I. Solids, J. Am. Chem. Soc. 1946, 38, 2221-2295. 


\section{Supplementary information}

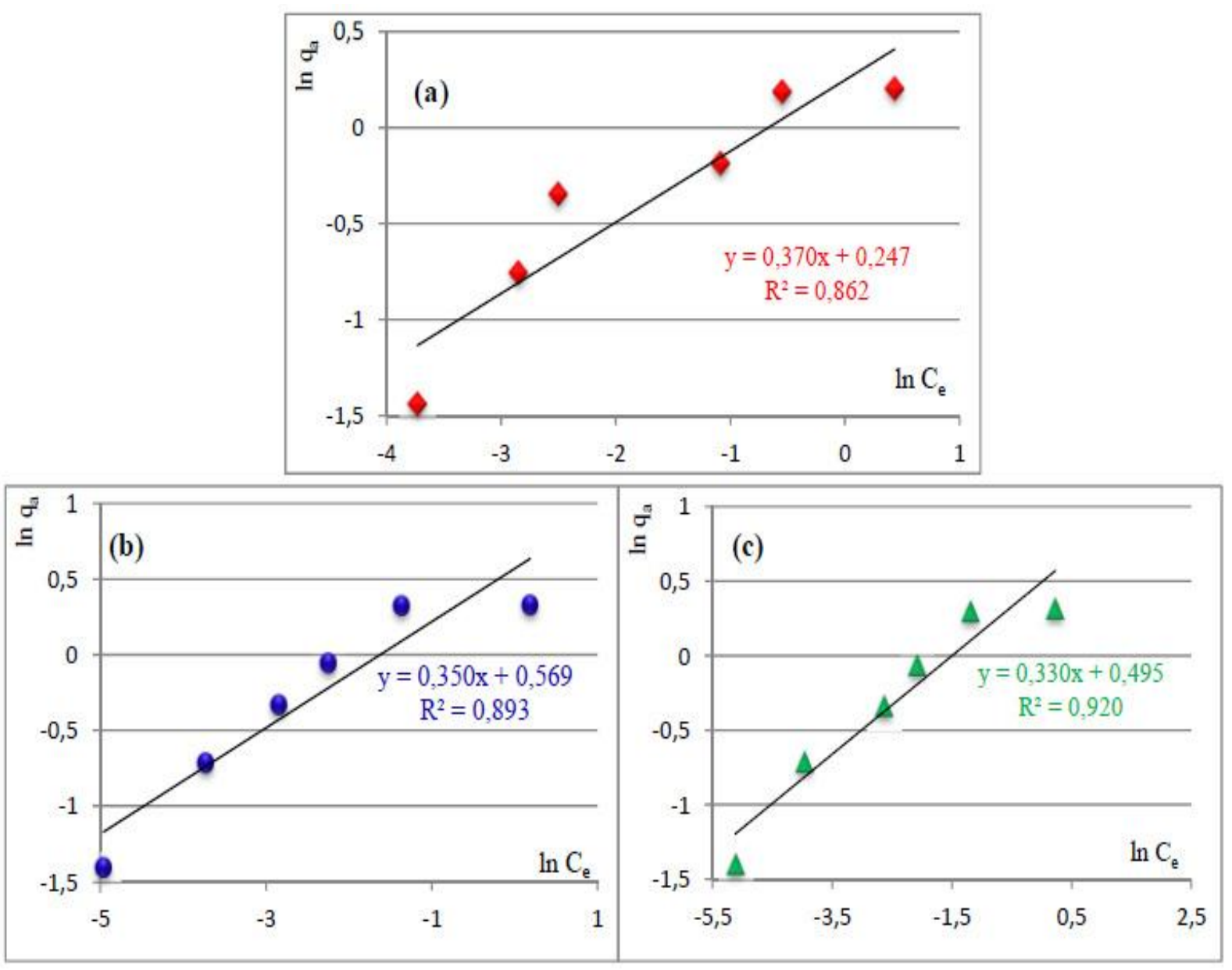

Figure S1. Freundlich isotherm plots for the adsorption of $\mathrm{Pb}^{2+}$ ions on CaHAp (a), CaHAp$\mathrm{Asp}_{10}$ (b) and CaHAp-Glu 10 (c) solids. 


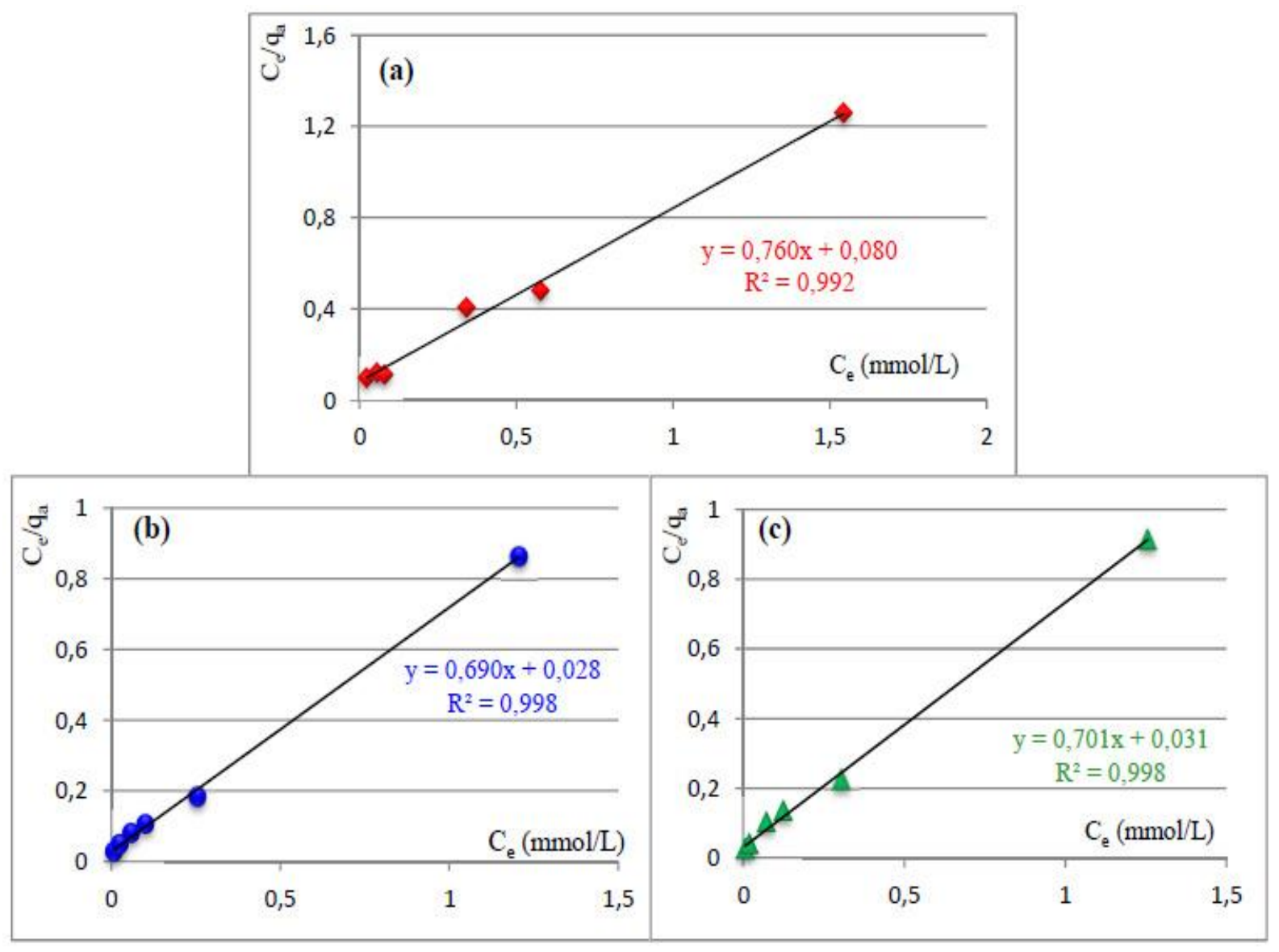

Figure S2. Langmuir isotherm plots for the adsorption of $\mathrm{Pb}^{2+}$ ions on CaHAp (a), CaHAp-Asp 10 (b) and CaHAp-Glu 10 (c) solids. 


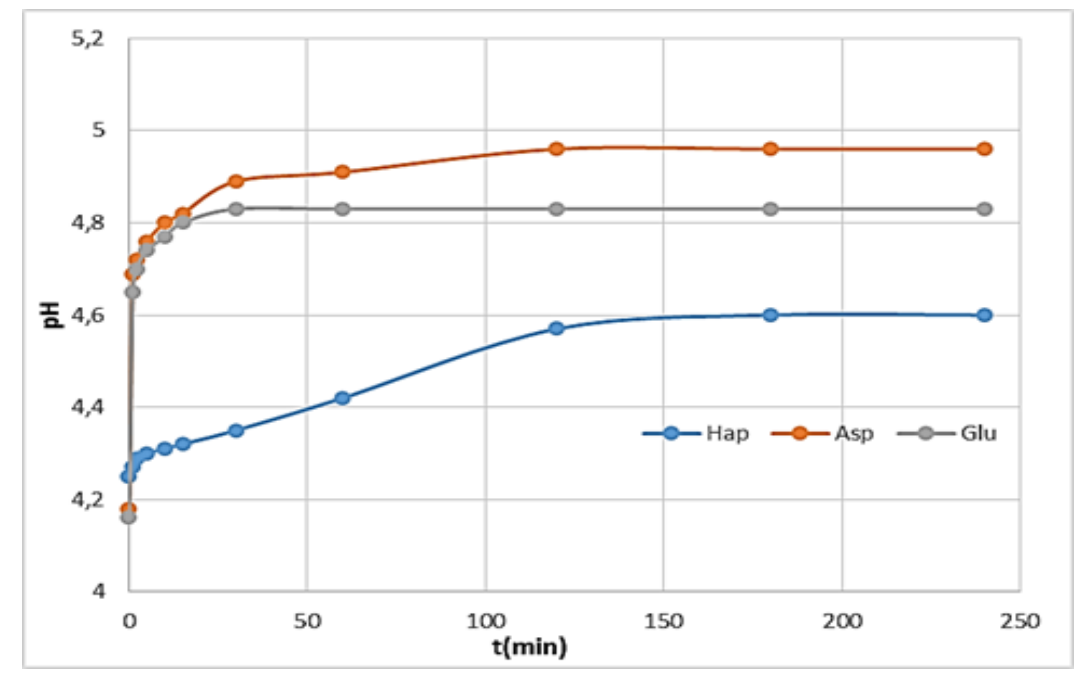

Figure S3. Evolution of $\mathrm{pH}$ upon contacting powders with $\mathrm{Pb} 2+$ solution $(\mathrm{pH}=5)$ 